\title{
PENGEMBANGAN DESAIN KURSI TAMAN BUNGKUL DENGAN MENGANGKAT TEMA SPARKLING SURABAYA
}

\author{
Suci Ramadhani \\ Prodi Arsitektur, Fakultas Teknik Sipil dan Perencanaan, Institut Teknologi Adhi Tama Surabaya, \\ Jl. Arief Rahman Hakim No. 100 Surabaya \\ Email: holy.sanz@gmail.com
}

\begin{abstract}
Abstrak
Taman Kota menjadi suatu Ruang Terbuka Hijau yang berfungsi sebagai paru-paru kota dan mengurangi masalah polusi dan kebisingan dan juga dapat menjadi sarana tempat berkumpulnya warga kota. Selain fungsi teknis dan fungsi sosial, keberadaan taman kota di Surabaya juga mengangkat nama Surabaya yang sekarang terkenal dengan sebutan Kota 1001 taman. Taman Bungkul yang terletak di Jalan Darmo, taman ini bukan hanya ramai pengunjung, tetapi juga masuk menjadi ikon Kota Surabaya. Kota Surabaya yang telah membuat jargon Sparkling Surabaya menjadi brand sejak tahun 2006 kurang memberikan kontribusi pada desain furnitur baik di jalanan protokol Kota Surabaya maupun di taman-taman kota. Hal ini tentu sangat disayangkan karena hal ini dapat menjadi salah satu ajang promosi Kota Surabaya baik di mata Nasional maupun Internasional. Metode penelitian yang digunakan adalah metode deskriptif komparatif, yaitu membuat uraian sistematis, faktual, dan akurat mengenai fakta serta keadaan obyek penelitian yang dilanjutkan dengan kajian komparatif untuk memahami keterkaitan diantara fakta yang ada. Dari hasil analisis yang dilakukan, baik melalui observasi, komparasi produk, maupun studi literatur, diperoleh data bahwa unsur Sparkling Surabaya yang terdapat pada elemen-elemen perkotaan menggunakan unsur tipografi, unsur warna dan pencahayaan. Desain akhir dari penelitian ini berupa rancangan kursi menerapkan tema Sparkling Surabaya.
\end{abstract}

Kata kunci: kota, kursi, sparkling, Surabaya, taman.

\section{Abstract \\ Title: Design Development of Bungkul Park Street Furniture Related to Sparkling Surabaya Theme}

City Park is an open green space that serves as the city's lungs and reduce the pollution and noise, and also can be a gathering place for city residents. In addition to the technical function and social function, a city park in Surabaya also raised Surabaya's image as a City which has 1001 parks. Bungkul Park is located in Darmo Street, this park is not only crowded, but also become one of an icon in Surabaya. Surabaya, which has made Sparkling Surabaya Theme became a brand since 2006, less contribute to the street furniture's design in the main streets of Surabaya and city parks. This is very unfortunate that it can be one of Surabaya's promotional event in national and international. The method of this research used comparative descriptive method, which make a systematic description, factual, and accurate about the facts and circumstances object of investigation that was followed by a comparative study to understand the interrelationships among facts. From the analysis conducted, either through observation, comparison of products, as well as literature study, the data showes that Surabaya Sparkling's elements contains typography, color and lighting factors. The final design of this research is a design of the street furniture of the park related to Sparkling Surabaya theme.

Keywords: city, park, street furniture, sparkling, Surabaya. 


\section{Pendahuluan}

Taman kota merupakan kawasan ruang terbuka hijau yang di dalamnya terdapat interaksi dan kegiatan sosial budaya, ekonomi, dan sekarang mulai berkembang menjadi sarana rekreasi bagi masyarakat. Taman kota sendiri berarti lahan terbuka yang berfungsi sosial dan estetik sebagai sarana rekreatif, edukasi atau kegiatan lain pada tingkat kota (Pedoman Penyediaan dan Pemanfaatan Ruang Terbuka Hijau di Kawasan Perkotaan, 2008). Fungsi awal diciptakannya taman kota adalah sebagai alun-alun dan taman raja, pamong praja dan juga terbuka untuk umum. Di zaman modern, dengan adanya perencanaan tata kota oleh pemerintah setempat, taman kota merupakan tempat umum untuk beristirahat yang dekat dengan perumahan dan sebagai pengatur iklim di suatu perkampungan.

Surabaya merupakan salah satu kota yang telah mengalami transformasi tata kota sejak di awal tahun 2010 dengan penambahan taman dengan jumlah yang sangat signifikan, sehingga Surabaya layak disebut sebagai kota seribu taman. Di setiap sudut di Kota Surabaya, terdapat setidaknya taman yang digunakan masyrakat untuk berkumpul bersama keluarga, bermain, maupun melakukan aktivitas belajar kelompok, karena beberapa taman di Surabaya telah dilengkapi dengan fasilitas Wi-Fi. Selain kebersihan yang selalu terjaga, ketersediaan sarana maupun prasarana di beberapa taman membuat masyarakat memiliki pilihan berekreasi di dalam kota.

Saat ini taman kota di Surabaya telah mencapai 54 taman, dengan memberikan tema yang sesuai dengan nama yang diberikan pada taman tersebut. Dari sekian banyak taman yang ada, taman yang paling populer menjadi tempat singgah warga kota Surabaya adalah Taman Bungkul yang terletak di Jalan Darmo Surabaya. Rata-rata taman ini dikunjungi minimal 150 orang per hari, bukan hanya anakanak maupun remaja yang berkunjung ke sini, namun juga orang dewasa maupun orang tua. Puncak terjadinya keramaian di Taman Bungkul adalah di akhir pekan, yaitu di hari Sabtu malam, karena terdapat theater di tengah taman yang berfungsi untuk mengadakan acara maupun kunjungan masyarakat pada car free day yang rutin diadakan pada Minggu pagi.

Sparkling Surabaya merupakan tema yang diangkat untuk mempromosikan Kota Surabaya dengan mengkomunikasikan bahwa Surabaya "Berkilau" dikarenakan gemerlap Kota Surabaya yang sekarang telah menjadi kota metropolitan. Jargon ini mulai diresmikan sejak tahun 2006 dengan tujuan mempromosikan Kota Surabaya agar menjadi salah satu destinasi yang nyaman dikunjungi. Walikota Surabaya, Tri Rismaharini mengatakan perlunya memberikan suatu penanda yang jelas bagi wisnu ataupun wisman yang datang ke Surabaya, penanda tersebut bukan hanya berupa peta lokasi yang tergambar secara on-line di situs resmi Kota Surabaya, tetapi juga terdapat di area-area yang menjadi tujuan wisata.

Secara historis, Kota Surabaya sudah ditata untuk memiliki penanda khususnya di pusat-pusat perdagangan sebagai penanda atau ikon yang telah menjadi identitas Kota Surabaya sebagai Kota Pahlawan. Ikon yang telah banyak dikenal yaitu Tugu Pahlawan, Patung Suro-Boyo yang berada di depan Kebun Binatang Surabaya, Hotel Majapahit, maupun Gedung Balai Kota. Namun penanda 
dalam skala kecil belum terlihat di kawasan kota Surabaya, khususnya di area taman kota yang kini menjadi sorotan. Dipermaknya taman-taman di Surabaya ikut menyegarkan wajah Kota Surabaya, dan dapat mengangkat nama Surabaya sehingga meningkatkan jumlah kunjungan wisatawan.

Pada Taman Bungkul yang menjadi taman idola warga Surabaya, penerapan tema sparkling belum terlihat secara maksimal, khususnya pada furnitur taman seperti kursi taman, tempat sampah, maupun lampu taman. Furnitur taman yang berfungsi sebagai pelengkap aktivitas pengunjung seharusnya dapat menjadi objek promosi Jargon Sparkling Surabaya, terutama dengan perkembangan media on-line yang menjadi salah satu ajang promosi. Terdepat beberapa kursi beton di Taman Bungkul, seperti Gambar 1.

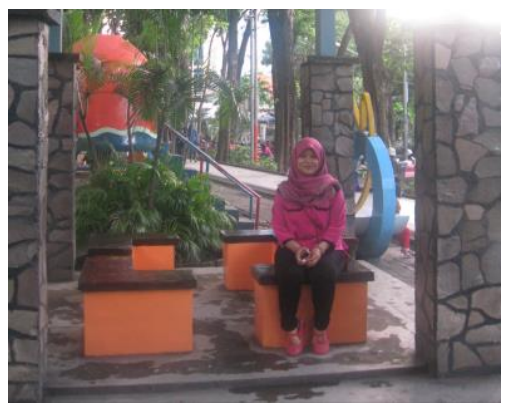

Gambar 1. Kursi di Taman Bungkul

Surabaya

Sumber: Dokumentasi pribadi, 2016

Desain kursi taman belum mendukung tema promosi, sehingga ketika pengunjung datang dan berfoto tidak memberikan suatu kesan dan belum memberikan "nilai jual". Dengan mengaplikasikan tema sparkling pada furnitur taman Bungkul terutama pada desain kursi, diharapkan dapat menjadi suatu penanda Kota Surabaya dan menjadi media promosi untuk wisata Kota Surabaya.

\section{Metode Penelitian}

Penelitian ini merupakan penelitian kualitatif, dengan menggunakan metode deskriptif komparatif dan analisis visual desain, yaitu membuat uraian sistematis, faktual dan akurat mengenai fakta objek penelitian yang dilanjutkan dengan kajian komparatif untuk memahami keterkaitan antara fakta yang ada dengan desain kursi taman yang ada di beberapa negara dengan penerapan suatu tema. Langkah-langkah penelitian meliputi pengumpulan data mengenai kondisi eksisting kursi di Taman Bungkul, dan menganalisis tema Sparkling yang menjadi Tema Kota Surabaya dengan metode visual analisis. Metode visual analisis merupakan metode analisis dengan melihat unsur bentuk, warna, pencahayaan, dan semiotika dari objek yang ada (Rose, 2001). Dari hasil analisa maka didapatkan sintesa desain suatu kursi taman yang menerapkan dan mengangkat tema Sparkling Surabaya.

\section{Hasil dan Pembahasan}

Desain merupakan suatu kegiatan manusia untuk menciptakan lingkungan dan khasanah perbendaan buatan yang diolah dari alam. Khasanah ini kemudian berkembang melalui inovasi-inovasi yang menciptakan kehidupan budaya manusia yang lebih baik (Sachari, 2007). Produk desain yang menyangkut rancang bangun, fashion, produk industri, maupun interior adalah sebuah potensi yang dekat dengan keseharian masyarakat. Sebuah produk desain akan mendapatkan poin tersendiri bagi masing-masing individu sehingga persaingan akan semakin ketat terkait dari segi desain yang dibuat, bahan, hingga media promo yang dilakukan. 
Dengan berkembangnya teknologi yang ada, inovasi yang dikembangkan semakin banyak dan membuat minat serta daya saing akan suatu produk semakin tinggi. Furnitur kota yang terletak pada suatu tempat yang signifikan adalah salah satu elemen penting untuk menyampaikan suatu maksud kepada masyarakat (Bulduk, 2012).

Taman kota memiliki fungsi sebagai estetika yang bukan hanya dari warna, bentuk dan keindahan dari vegetasi yang ada di dalam taman, namun juga furnitur pendukung seperti kursi taman, lampu taman, maupun tempat sampah. Adanya hubungan antara furnitur taman dan dengan lingkungan sekitarnya mempengaruhi kualitas estetika pada taman tersebut. Pengembangan desain furnitur taman kota, khususnya kursi, yang menjadi salah satu furnitur utama pada suatu taman membutuhkan transformasi rancangan yang dapat membangun imej suatu area maupun suatu kota.

Hal ini bisa terlihat dari beberapa contoh pengembangan desain kursi taman yang terdapat di Belanda, Inggris, Cina, dan Negara maju lainnya yang menguatkan tema pada rancangan furnitur kota untuk menciptakan imej yang kuat kepada orang yang datang dan merasakan sensasi yang berbeda, seperti yang terlihat pada Gambar 2 . Kursi Tulpi yang terdapat di Belanda.

Kursi Tulpi merupakan hasil rancangan dari Marco Manders, seorang desainer asal Nieuwegein, Belanda yang terinspirasi dari bunga tulip yang merupakan ciri khas negara tersebut. Sehingga ketika seseorang melihat foto dari kursi taman ini, hal pertama yang terbersit adalah Negara Belanda yang telah terkenal dengan keindahan bunga tulipnya (Putri, 2015, diakses dari http://hwc2015.nvo.or.id pada 10 November 2016).

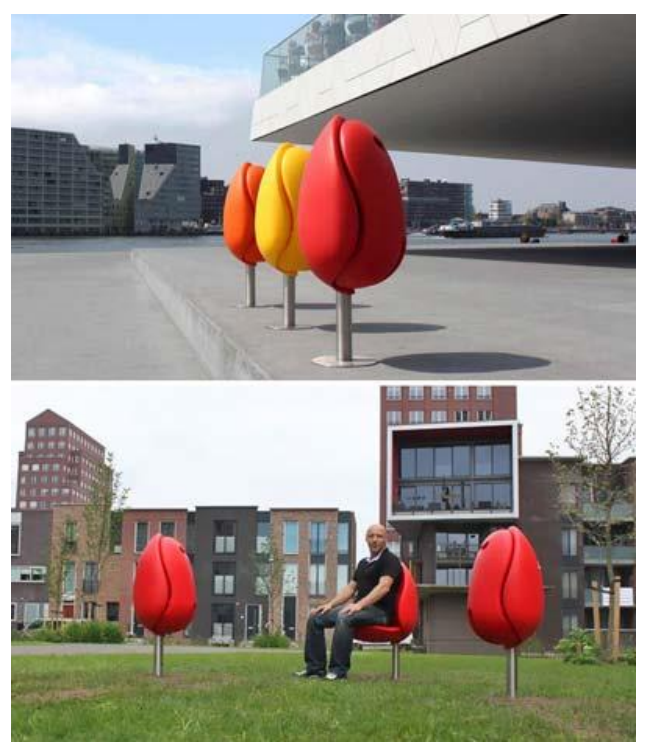

Gambar 2. Kursi Tulpi Belanda

Sumber : www.tipsiana.com, diakses 11

November 2016

Kursi Tulpi ini dirancang bukan hanya memenuhi estetika bentuk yang mengambil bentuk bunga tulip, tetapi juga kebutuhan pengguna kursi yang tidak perlu khawatir jika kursi tersebut basah ketika hujan karena kursi ini memiliki sistem lipat pada area duduk yang ketika tidak digunakan dapat dilipat sehingga memiliki bentuk seperti bunga tulip.

Perbandingan lain yang dapat dijadikan referensi dalam pengembangan desain kursi yang akan menyerap tema kota adalah desain kursi taman di Kowloon Tong Cornwall Street Hongkong yang mengangkat tema Future City sebagai branding Kota Hongkong. Keterbatasan lahan membuat kota ini memiliki arsitektur dengan teknologi tinggi terhadap bangunan vertikal. Kota Hongkong yang terkenal sebagai kota yang menyokong perekonomian Negara Cina, dan disebut sebagai New York of China ini merupakan sebuah kota metropolitan yang mengusung tema kota masa depan sehingga tema 
ini diaplikasikan dalam bentuk dinamis desain kursi di Kowloon Tong Cornwall Street. Bentuk dinamis yang dimaksudkan bukan hanya mengacu pada tema futuristik yang menjadi ide awal, tetapi juga dikarenakan mengikuti bentuk tubuh pengguna. Seperti yang diketahui bahwa pola hidup masyarakat di kota telah menjadikan warga di Kota Hongkong kesulitan dalam berkomunikasi, sehingga diharapkan perancangan kursi di Kowloon Tong Cornwall Street dapat menjadi sarana warga kota untuk saling berkomunikasi, seperti pada Gambar 3.

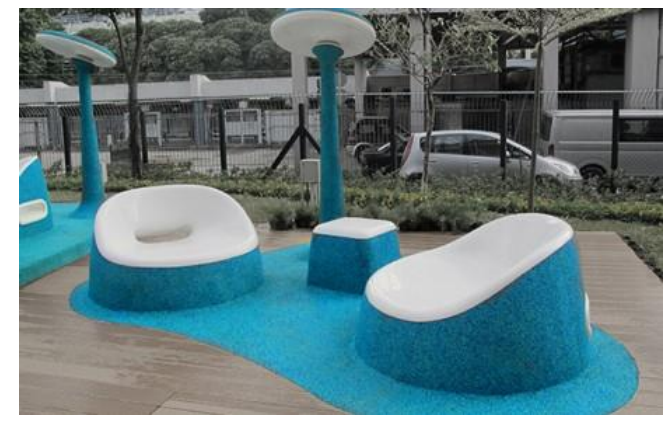

Gambar 3. Kursi di Kowloon Tong

Cornwell Street Hongkong

Sumber : www.el23.hk, diakses pada 10

November 2016

Desain kursi pada Kowloon Tong Cornwell Street diharapkan dapat meningkatkan kualitas hidup bagi warga Kota Hongkong dan juga dapat sebagai penanda di kawasan Cornwell Street (Lee. B, dkk. 2012). Menurut Departemen Kenyamanan dan Pelayanan Budaya Kota Hongkong bekerja sama dengan Pusat Desain Hongkong menciptakan karakteristik futuristik terhadap kursi taman sehingga ketika berada di tempat tersebut, maka akan terasa berada di dimensi yang lain (www.e123.hk) seperti yang terlihat pada Gambar 4 .

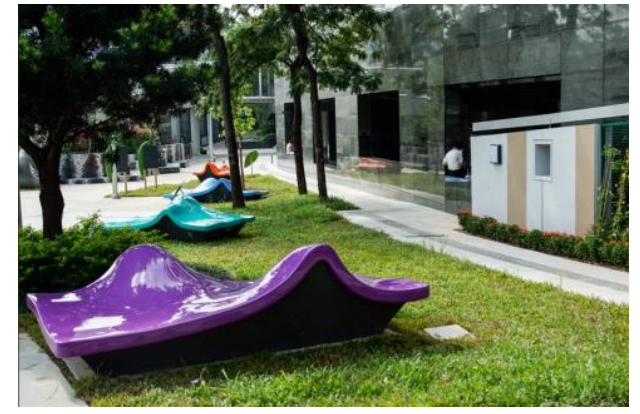

Gambar 4. Kursi di Kowloon Tong

Cornwall Street Hongkong

Sumber : www.el23.hk, diakses pada 10

November 2016

Dari analisis perbandingan terhadap dua taman kota di negara lain, maka dapat dilihat bahwa desain kursi pada taman yang ada di Belanda dan Hongkong mendapatkan ide dari tema pada negara atau kota tersebut. Namun, ide konsep desain tersebut tentunya harus didukung oleh kebutuhan pengguna.

\section{Analisis Visual pada Penerapan Tema Sparkling Surabaya}

Saat ini di beberapa kota besar di Indonesia telah menggunakan suatu tema untuk memperkenalkan kota tersebut kepada masyarakat, sehingga tercipta suatu identitas yang dapat dikenal dari kota-kota tersebut Sparkling Surabaya adalah salah satu contoh konsep promosi yang menciptakan kesan "berkilau" kepada masyarakat. Konsep ini tercipta dari gemerlap kota dan imej metropolitan pada Kota Surabaya dan memberikan imej "Kota Perhiasan" pada Surabaya, konsep ini telah diluncurkan sejak tahun 2006 namun masih menjadi perdebatan, dikarenakan belum mengangkat budaya Surabaya sehingga penerapan konsep Sparkling Surabaya hanya terlihat di beberapa spot di Kota Surabaya. Awal mula aplikasi tema ini terdapat pada Bus Kota, atas kerjasama Pemkot Surabaya dengan Perum Damri. Logo Sparkling Surabaya 
menempel pada kaca belakang Bus Damri seperti pada Gambar 5.

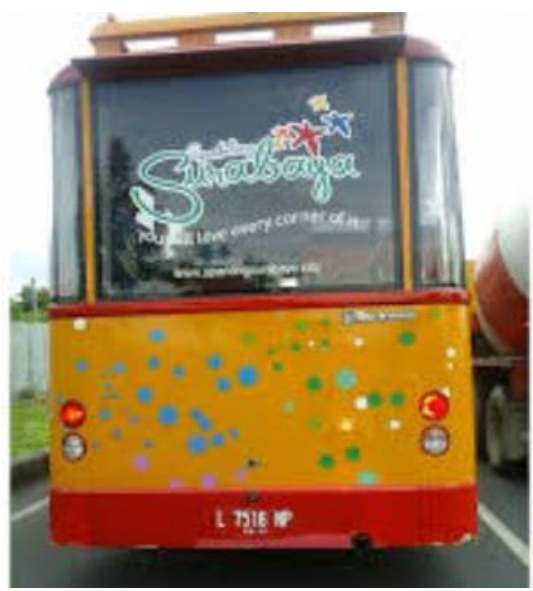

Gambar 5. Bus Damri Kota Surabaya

Sumber : Dokumentasi pribadi, 2016

Tujuan dibuatnya jargon ini adalah untuk memberikan kesan kepada pengunjung mengenai tempat-tempat di Surabaya sehingga dengan melihat logo tersebut pengunjung akan ingat akan keindahan Kota Surabaya. Selain kesan berupa logo yang ditempelkan di beberapa Bus Kota dan di papan iklan yang ada di pinggir jalan Kota Surabaya, Dinas Pertamanan memberikan make-up pada wajah taman Kota Surabaya contohnya di Taman Bungkul, Taman Pelangi dan beberapa taman kota lainnya di Surabaya. Namun sayangnya penerapan ini dinilai belum maksimal dan belum menyentuh area bagian dalam taman yaitu kursi taman maupun furnitur taman lainnya.

Ketertarikan wisnu (wisatawan nusantara) dan wisman (wisatawan mancanegara) untuk mengunjungi sebuah kota tentu berawal dari adanya pencitraan kota tersebut. Pencitraan sebuah kota dapat dilakukan agar memberikan identitas pada kota tersebut. Dengan demikian, potensi sebuah kota dapat lebih terekspos. Sebagai contoh, ibukota Indonesia yaitu kota Jakarta yang dikenal dengan istilah Enjoy Jakarta! Kalimat persuasif Enjoy Jakarta memiliki makna bahwa kota Jakarta merupakan kota megapolitan yang dipenuhi segala kebutuhan manusia mulai dari daily life (kebutuhan sehari-hari) hingga life style (gaya hidup). Penekanan citra Enjoy Jakarta merupakan sebuah ajakan untuk hidup lama dan bertempat tinggal di Jakarta dengan berbagai ketersediaan yang ada. Begitu pula dengan Sparkling Surabaya yang menggambarkan kilau Kota Surabaya, hal ini terlihat pada beberapa spot di Surabaya yang memberikan menunjukkan "kilauan" tersebut di Area Balai Kota Surabaya, dimana terdapat air mancur menari yang dihiasi dengan kelap kelip lampu pada malam hari. Balai Kota Surabaya merupakan salah satu spot yang ramai dikunjungi warga kota Surabaya baik hanya untuk berkunjung dan ada pula yang bermain air, khususnya di malam hari dan pada akhir pekan seperti yang terlihat pada Gambar 6.

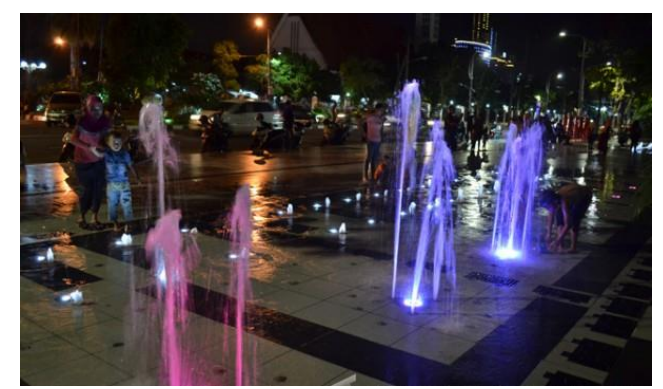

Gambar 6. Air mancur menari di balai kota Surabaya

Sumber : Dokumentasi pribadi, 2016

Awalnya penerapan tema sparkling terlihat pada Taman Pelangi di Jl. Ahmad Yani, dengan memberikan efek cahaya pada sculpture yang terdapat di tengah taman seperti yang terlihat pada Gambar 7. 


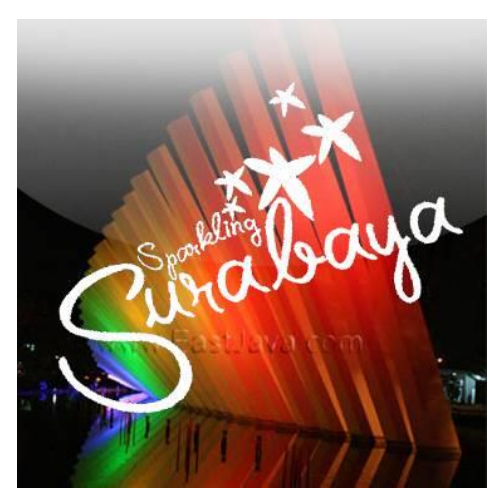

Gambar 7. Taman Pelangi Surabaya Sumber : Website Resmi Kota Surabaya, www.surabaya.go.id, diakses pada 10 Juli 2016

Desain sculpture yang dinamis dan membentuk seperti kipas yang terbuka memiliki warna putih dan terlihat jelas ketika siang hari, sedangkan ketika malam hari, sorotan lampu warnawarni pada batang-batang sculpture memberikan kesan kilauan pada Taman Pelangi.

Desain yang diterapkan pada beberapa spot di Surabaya sebagai ungkapan dari Tema Sparkling Surabaya merupakan suatu pesan kepada warga kota maupun pengunjung. Pettersson (2013) menjelaskan bahwa desain pesan (message design) adalah induk bagi tujuan yang berlainan. Komponen utama dalam desain pesan adalah katakata, visual dan bentuk. Komponenkomponen utama ini dapat digunakan dalam berbagai cara unik untuk menghasilkan, mentransmisikan dan menafsirkan pesan dari berbagai jenis dalam situasi komunikasi. Tergantung pada tujuan yang berbeda dari pesan, kita dapat melihat berbagai genus "desain pesan."

Implementasi lain dari tema sparkling pada Kota Surabaya selain memberikan efek sorotan cahaya warna-warni adalah memberikan sentuhan tipografi di pinggir jalan-jalan protokol di Surabaya, konsep ini merupakan suatu visual identity atau identitas yang menunjukkan suatu kota (Safanayong. 2007 dalam Indrojarwo, dkk. 2011). Bentuk "penanda" pada jalan-jalan di Surabaya berupa bentuk-bentuk alfabet yang menuliskan nama jalan atau nama tempat. Hal ini terkait dengan Teori Gestalt adalah sebuah teori yang menjelaskan proses persepsi melalui pengorganisasian komponenkomponen sensasi yang memiliki hubungan, pola, ataupun kemiripan menjadi kesatuan. Teori Gestalt cenderung berupaya mengurangi pembagian sensasi menjadi bagianbagian kecil.

Teori Gestalt banyak dipakai dalam proses desain dan cabang seni rupa, karena banyak menjelaskan bagaimana persepsi visual dapat terbentuk. Persepsi jenis ini bisa terbentuk karena Kesamaan bentuk (similarity) yang menyatakan bahwa otak memberikan pilihan, manusia akan memilih bentuk paling sederhana dan stabil untuk berkonsentrasi. Pemberian tanda jalan dengan ukuran dan warna yang mencolok, sehingga menjadikan tulisan tersebut menjadi imej pada jalan-jalan protokol yang ada di Surabaya, seperti yang terlihat pada Gambar 8.

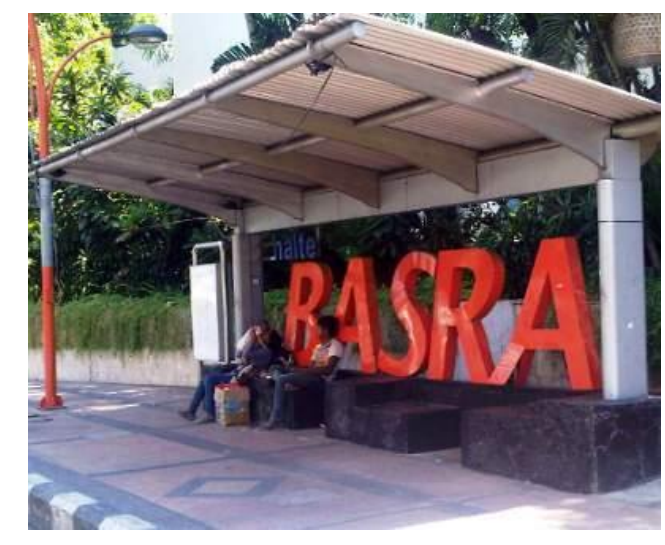

Gambar 8. Halte Basuki Rahmat Surabaya Sumber : Dokumentasi pribadi, 2016 
Dari analisis obyek-obyek yang menjadi landmark Kota Surabaya, terdapat unsur-unsur visual yaitu unsur pencahayaan yang terdapat pada air mancur, unsur warna mencolok, dan terutama unsur bentuk yang mengangkat semiotika yaitu sebagai penanda area dengan teknik tipografi.

Taman Bungkul Surabaya

Taman Bungkul merupakan taman seluas $\pm 900 \mathrm{~m}^{2}$ yang telah diresmikan sejak tahun 2007. Pemberian nama Bungkul diambil dari seorang tokoh yang sangat berpengaruh dalam penyebaran agama Islam di wilayah Surabaya dan sekitarnya, yaitu Ki Ageng Supo yang lebih dikenal dengan nama Mbah Bungkul. Taman yang memiliki sarana penunjang seperti skateboard track, BMX track, jogging track, plaza yang dilengkapi dengan amfiteater beton, zona untuk mengakses Wi-Fi yang disponsori oleh PT Telkom, area green park dengan air mancur, area bermain anak, serta pujasera di bagian belakang Taman Bungkul. Pada Tahun 2013, taman ini mendapatkan penghargaan dari Perserikatan Bangsa-Bangsa sebagai taman terbaik se-Asia dalam penghargaan The 2013 Asian Townscape Award.

Dari observasi yang telah dilakukan, implementasi tema sparkling sudah cukup diterapkan di Taman Bungkul, hal ini terlihat dari kesamaan penanda yang terdapat di area depan Taman Bungkul yang menggunakan seni tipografi seperti pada Gambar 9.

Taman Bungkul Surabaya juga menunjukkan kilauannya pada malam hari melalui pilar-pilar yang terdapat di bagian belakang amfiteater. Lampulampu TL berwarna merah, biru ditempelkan pada pilar-pilar sehingga membuat efek menyala seperti pada Gambar 10.

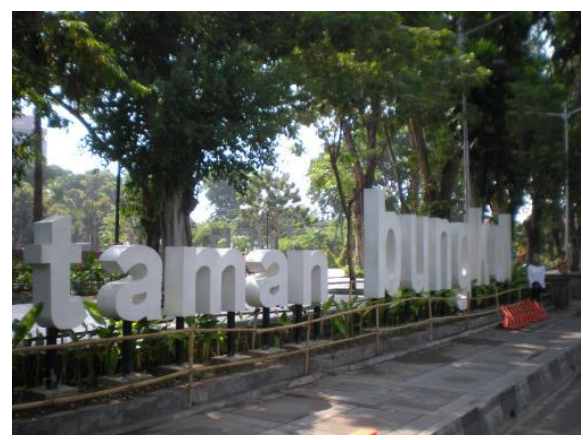

Gambar 9. Bagian Depan Taman Bungkul Surabaya

Sumber: Dokumentasi pribadi, 2016

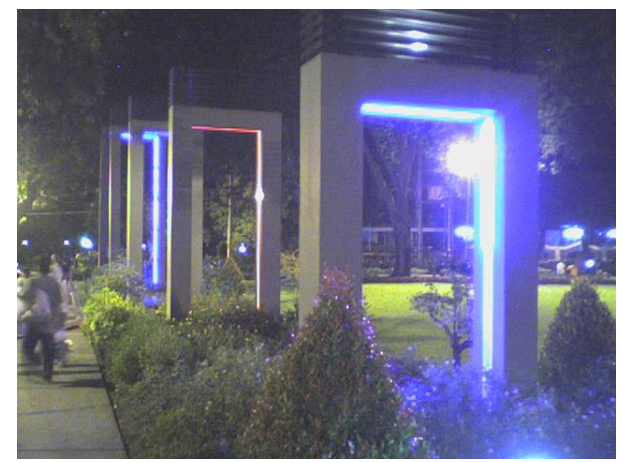

Gambar 10. Suasana Taman Bungkul pada Malam Hari

Sumber : Dokumen pribadi, 2016

Terdapat 3 jenis kursi di Taman Bungkul, untuk menampung jumlah pengunjung yang sangat banyak, khususnya di malam hari dan di akhir pekan. Kursi utama yang disediakan oleh Pemerintah Kota Surabaya berupa kursi amfiteater yang biasanya digunakan untuk mengadakan pertunjukan, maupun menjadi tempat untuk bermain in-line skate. Di pinggiran amfiteater terdapat area duduk dan berkumpul yang terbuat dari semen cor seperti pada Gambar 11. 


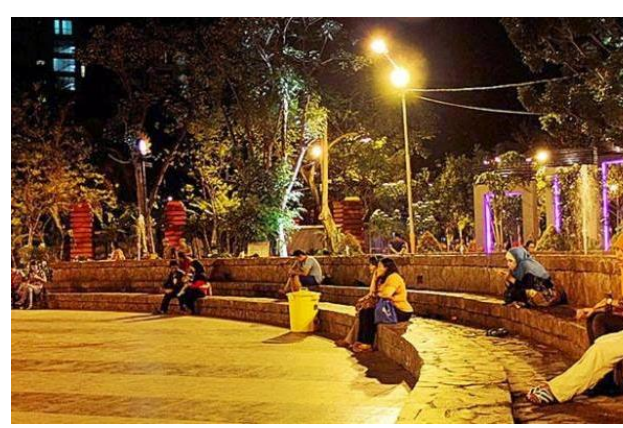

Gambar 11. Kursi di Amfiteater Taman Bungkul

Sumber : Dokumentasi pribadi, 2016

Selain area amfiteater, terdapat juga beberapa kursi di area bermain, dan di area belakang amfiteater yang salah satunya diberi aksen logo PT Telkom yang menjadi sponsor akses Wi-Fi di Taman Bungkul seperti yang terlihat pada Gambar 12.

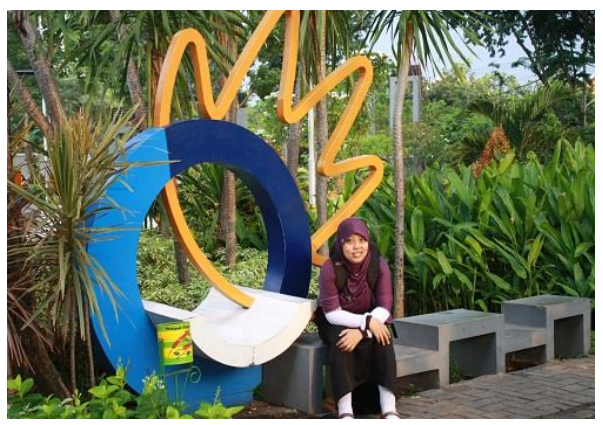

Gambar 12. Logo PT Telkom pada Kursi Taman Bungkul

Sumber : Dokumentasi pribadi, 2016

\section{Pengembangan Desain berdasarkan Analisis Visual Desain}

Pengembangan desain kursi di Taman Bungkul dilakukan setelah melakukan komparasi kursi taman di beberapa negara dengan mengangkat tema dari negara tersebut. Selain melakukan komparasi, dilakukan analisis deskriptif visual terhadap desain beberapa objek yang telah menerapkan tema sparkling, seperti pada Halte di Jl Basuki Rahmat, yang menerapkan seni tipografi sebagai penanda area. Tipografi merupakan bagian dari semiotika, yaitu suatu seni yang menonjolkan karakter huruf dengan tema tertentu sehingga dapat membangun suatu imej. Menurut Manuale Typographicum (1954) dalam Sufiana (2011), mengatakan bahwa dengan memilih dan menata huruf dengan pengaturan penyebaran pada ruang-ruang yang tersedia, seni tipografi dapat memberikan suatu kesan khusus yang menjadikan orang yang melihat mendapatkan suatu kenyamanan.

Penerapan tipografi pada taman-taman di Kota Surabaya biasanya hanya sebagai penanda taman dengan menyusun huruf yang terangkai menjadi nama taman dan ditempatkan di area depan atau area masuk pengunjung taman. Adapun Taman Pakal yang terletak di Surabaya Barat memberikan aksen tipografi pada sculpture yang dikelilingi oleh kursi cor, namun huruf hanya sebagai aksen pembatas pinggiran sculpture, seperti yang terlihat pada Gambar 13.

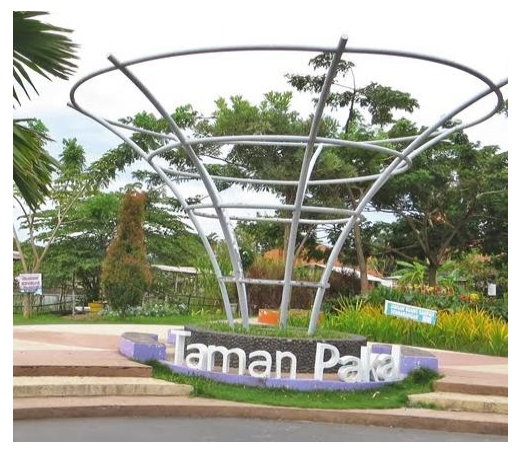

Gambar 13. Taman Pakal Surabaya Timur Sumber : Dokumentasi pribadi, 2016

Dari unsur tipografi yang memberikan imej yang kuat terhadap branding Sparkling Kota Surabaya, maka ide awal dari pengembangan desain kursi taman ini menggunakan huruf yang menyusun nama Taman Bungkul yang difungsikan sebagai kursi, seperti yang terlihat pada Gambar 14. 


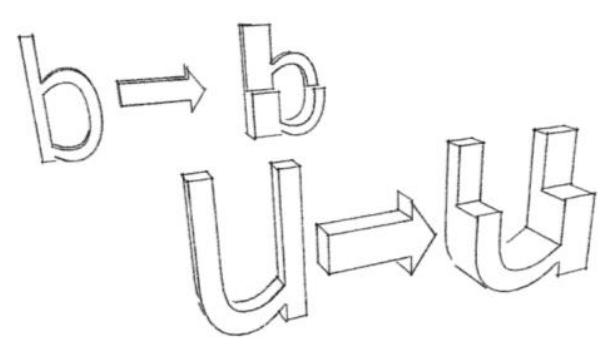

Gambar 14. Sketsa awal pengembangan desain

Sumber : Hasil analisis, 2016

Penerapan lain dari hasil analisis visual yang mendukung tema sparkling adalah unsur warna alami dan warna buatan yang didukung oleh suatu pencahayaan. Unsur warna alami dapat terlihat pada siang hari, dimana warna asli pada objek terlihat jelas dikarenakan cahaya yang dipancarkan secara alami oleh matahari. Warna merupakan elemen yang sangat penting dalam seni terutama pada seni lukis, karena warna sebagai efek cahaya yang memberi kesan pada mata, sehingga dapat menghadirkan karakter dari suatu bentuk yang secara psikologis mempengaruhi perasaan. Menurut Darmaprawira (2002) dalam Gulendra (2010) bahwa warna dapat mempengaruhi jiwa manusia dengan kuat atau dapat mempengaruhi emosi manusia. Warna juga dapat menggambarkan suasana hati.

Warna yang banyak digunakan pada elemen yang mencerminkan sparkling di Kota Surabaya lebih banyak menggunakan warna putih dan warna merah, seperti yang terlihat pada Gambar 15, pada tulisan Balai Kota yang berdekatan dengan air mancur menari di halaman Kantor Balai Kota Surabaya.

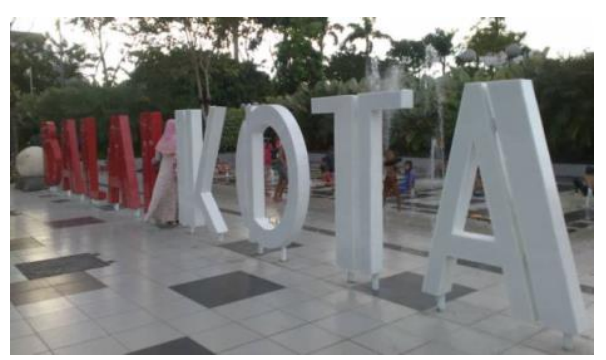

Gambar 15. Landmark Balai Kota Surabaya Sumber : Dokumentasi Pribadi, 2016

Dari analisis warna yang telah dilakukan, sehingga warna yang digunakan agar tetap selaras dengan elemen-elemen kota yang telah ada digunakan warna merah dan putih, seperti yang terlihat pada Gambar 16.

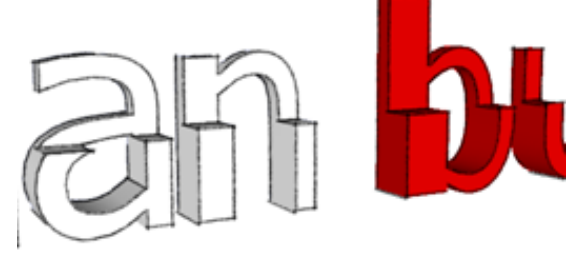

Gambar 16. Penerapan warna terhadap desain

Sumber : Hasil analisis, 2016

Dalam unsur perancangan, hal yang berpengaruh bukan hanya mengenai bentuk, warna, dan juga tekstur, tetapi adanya suatu cahaya buatan yang mendukung menciptakan suasana berkilau. Faktor-faktor penting dalam penerapan pencahayaan terhadap suatu objek adalah warna cahaya, warna objek, warna refleksi cahaya yang dihasilkan, dan arah cahaya (Harjanto, 2009). Aksen warna dan pencahayaan menjadi daya tarik yang kuat dari air mancur menari yang terdapat di Jembatan Kenjeran Surabaya seperti pada Gambar 17. 


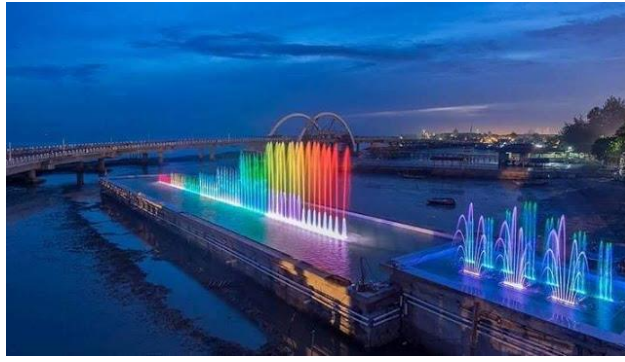

Gambar 17. Air mancur menari jembatan Kenjeran Surabaya

Sumber : Dokumentasi Pribadi, 2016

Dari unsur pencahayaan yang telah di kaji sesuai dengan hasil observasi dan kajian teori visual desain, maka penggunaan warna cahaya kuning sebagai latar dari kursi taman ini dilakukan agar timbul keseimbangan antara bentuk, warna dan cahaya pada desain. Karena pemberian cahaya yang terlalu mencolok dapat menghilangkan esensi dari bentuk dan warna yang telah ada. Lampu diletakkan di bagian belakang dari masing-masing kursi dan memberikan efek menyebar di sekitar kursi taman seperti pada Gambar 18.

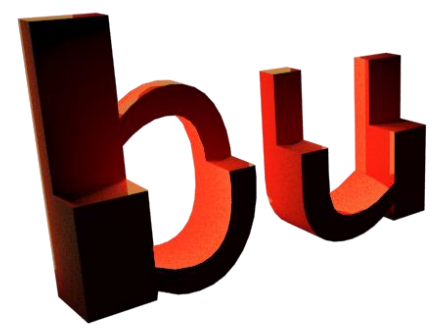

Gambar 18. Penerapan pencahayaan pada desain

Sumber : Hasil analisis, 2016

\section{Desain Akhir}

Setelah melakukan studi perbandingan dengan kursi taman dari negara lain, melakukan observasi dan tinjauan pustaka, maka desain akhir dari pengembangan kursi di Taman Bungkul adalah rangkaian huruf yang membentuk tulisan Taman Bungkul. Penggunaan huruf disesuaikan dengan jenis huruf yang telah digunakan pada elemen penanda seperti di Balai Kota maupun di Halte Basuki Rahmat. Penggunaan warna merah dan putih dan diberikan efek cahaya dari bagian belakang kursi. Jika dilihat dari tampak depan secara garis lurus, maka kursikursi tersebut jelas terbaca sebagai rangkaian huruf, dan jika dilihat secara perspektif maka akan ada bagian menonjol yang difungsikan sebagai kursi, seperti pada Gambar 19 dan Gambar 20.

\section{teman bungkul}

\section{Gambar 19. Tampak depan desain akhir} kursi

Sumber : Hasil analisis, 2016

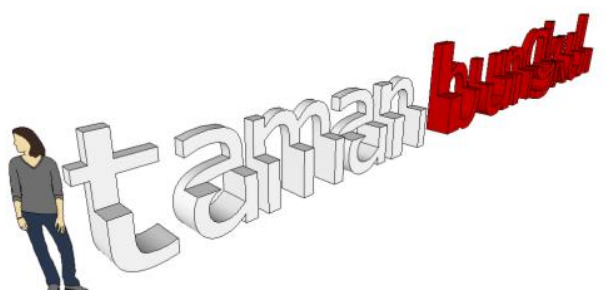

Gambar 20. Tampak perspektif desain akhir kursi

Sumber : Hasil analisis, 2016

\section{Penempatan Desain}

Penempatan desain kursi di Taman Bungkul menyesuaikan dimensi keseluruhan kursi yang kira-kira membutuhkan ruang seluas $7 \mathrm{~m}^{2}$, dan area tersebut terdapat di bagian belakang amfiteater, seperti pada Gambar 21, dan Gambar 22 menunjukkan pencahayaan kursi ketika malam hari. 


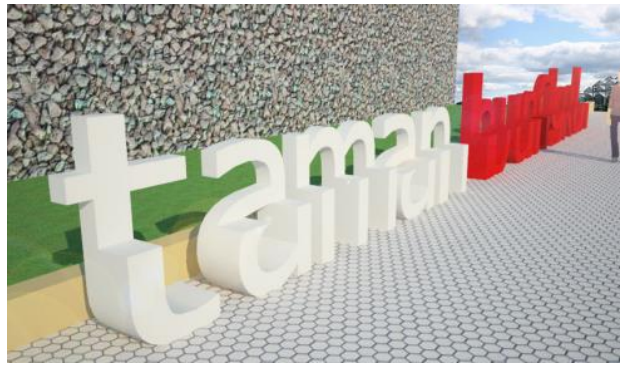

Gambar 21. Gambar perspektif desain akhir Sumber : Hasil analisis, 2016

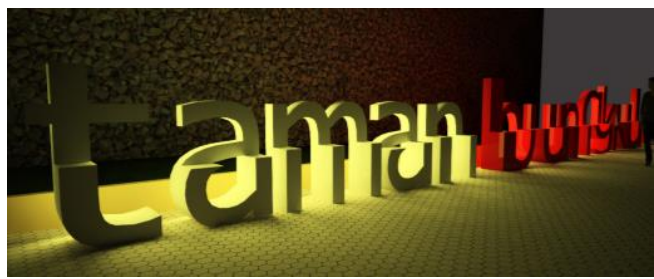

Gambar 22. Gambar perspektif desain akhir pada malam hari

Sumber : Hasil analisis, 2016

\section{Kesimpulan}

Dari observasi dan analisis yang telah dilakukan, maka dapat disimpulkan bahwa :

1. Furnitur pada taman kota, salah satu contohnya adalah kursi taman, dapat menjadi suatu ikon untuk menguatkan imej suatu kota.

2. Penerapan tema Sparkling Surabaya pada elemen furnitur seperti penanda pada jalan protokol dan area rekreasi telah terlihat, namun belum terlalu kuat pada furnitur pada taman-taman kota.

3. Konsep sparkling yang muncul pada desain elemen yang telah ada, yaitu konsep tipografi, konsep warna dan pencahayaan, ketiga hal ini masuk dalam teori visual desain.

4. Dari analisis visual desain yang telah dilakukan, maka pengembangan desain kursi pada Taman Bungkul mengadopsi konsep tipografi, warna, dan pencahayaan seperti desain yang telah ada.

\section{Daftar Pustaka}

Altman, I. (1975). The environmental and social behaviour. California: Brooks/Cole Publishing Company.

Bulduk, B. (2012). An analysis of the use of urban furniture in city advertising in terms of aesthethic/visual appreciation training. City Design. ProcediaSocial and Behavioural Science 46 ; p: 3279 - 3283. ISSN : 1877-04281.

Departemen PU. (2008) Pedoman penyediaan dan pemanfaatan ruang terbuka hijau di kawasan perkotaan. Dirjen Penataan Ruang.

Gulendra, I Wayan. (2010). Pengertian warna dan tekstur. (jurnal online).

http://jurnal.isidps.ac.id/index.p

hp/artikel/article/view/323 di akses 10 Oktober 2016

Harjanto, R. (2009). Prinsip-prinsip periklanan. Jakarta: PT Gramedia.

Indrojarwo, Baroto T., \& Sabar, Z. (2011). Visual design study of city branding of Surabaya as a national creative industry center with MDS method. Surabaya: ITS.

Lee, B., Chan, YH., Denise, LH., Tang, MX. (2012). Park seating furniture design in Hong Kong: A case study of inclusive design and its relation to user interaction. school of design. The Hong Kong Polytechnic University.

Pettersson, R. (2013). Information design: Message design, international institute for information design (IIID) 1170 Wien. Austria: Palffygasse 27 / 17. 
Rose, G. (2001). Visual methodologies. London: SAGE Publication.

Sachari, A. (2007). Desain gaya dan realitas. Jakarta: Penebar Swadaya.

Sufiana. (2011). Analisis semiotika tipografi alien sebagai media pembelajaran huruf pada anak usia dini (studi kasus poster i'm alien 'you). Prosiding Konferensi Nasional "Inovasi Dalam Desain dan Teknologi" IDeaTech 2011. ISSN : 20891121. 